\title{
Communication/Comunicação
}

\section{Comparison among three polymerase chain reaction assays on detection of DNA from Leishmania in biological samples from patients with} American cutaneous leishmaniasis

\author{
Comparação entre três ensaios de reação em cadeia da polimerase na detecção de DNA de \\ Leishmania, em amostras biológicas de pacientes com leishmaniose tegumentar americana
}

\section{João Guilherme Lino da Silva ${ }^{1}$, Thiago Miranda da Silva ${ }^{2}$, Eduardo de Figueiredo Peloso' ${ }^{2}$, George Luiz Lins Machado-Coelho ${ }^{3}$, Wilson Mayrink ${ }^{4}$, Marília Caixeta Franco Ariosa ${ }^{1}$, Paulo Márcio de Faria e Silva ${ }^{1}$ and Marcos José Marques ${ }^{1}$}

\begin{abstract}
Introduction: The study analyzed positivity of polymerase chain reaction (PCR) on detection of DNA from Leishmania in patients' samples. Methods: Extracted DNA was submitted to L150/L152, 13Y/13Z, and seminested PCR (snPCR). Results: Results were evidenced by bands of approximately 120,720 , and $670 \mathrm{bp}$ for L150/L152, 13Y/13Z, and snPCR, respectively. L150/L152, 13Y/13Z, and snPCR positivity indexes were 76.9, 56.4, and $69.2(p>0.05)$, respectively, for suspected and $93.7,68.7$, and $84.4(p<0.05)$, respectively, for confirmed. Conclusions: Preliminary results showed that these assays, mainly L150/L152 and snPCR, can detect Leishmania DNA and carry potential on laboratory diagnosis of leishmaniasis.
\end{abstract}

Keywords: Leishmania. PCR. Diagnosis.

\section{RESUMO}

Introdução: Analisou-se a positividade da reação em cadeia da polimerase (PCR) na detecção de DNA de Leishmania em pacientes. Métodos: DNA extraído foi submetido a L150/L152, 13Y/13Z e PCR seminested (snPCR). Resultados: Resultados foram evidenciados por bandas de aproximadamente 120; 720 e 670pb para L150/L152, 13Y/13Z e snPCR, respectivamente. Positividades para L150/L152, 13Y/13Z e snPCR foram 76,9; 56,4 e 69,2 ( $\mathrm{p}>0,05$ ), para suspeitos; e 93,7; 68,7 e 84,4 ( $<<0,05)$ para confirmados, respectivamente. Conclusões: Resultados preliminares mostraram que os ensaios, principalmente L150/L152 e snPCR, podem detectar DNA de Leishmania e têm potencial para diagnóstico laboratorial das leishmanioses.

Palavras-chaves: Leishmania. PCR. Diagnóstico.

Leishmaniases are caused by an intracellular protozoan of the genus Leishmania, whose promastigote forms can be transmitted to humans by the bite of Lutzomyia female insect, also known as sandfly ${ }^{1}$.

Leishmania infection occurs in most Brazilian states, and some authors believe that its dispersal is associated to anthroponotic action. The traditional clinical manifestations for American cutaneous

1. Laboratório de Biologia Molecular de Microorganismos, Universidade Federal de Alfenas, Alfenas, MG. 2. Instituto de Biologia, Universidade Estadual de Campinas, Campinas, SP. 3. Departamento de Ciências Médicas, Universidade Federal de Ouro Preto, Ouro Preto, MG. 4. Instituto de Ciências Biológicas, Universidade Federal de Minas Gerais, Belo Horizonte, MG.

Address to: Dr. João Guilherme Lino da Silva. Laboratório Biologia Molecular de Microorganismos/UNIFAL. Rua Gabriel Monteiro da Silva 714/sala Q107, 37130-000 Alfenas, MG, Brasil.

Phone: 5535 3299-1475

e-mail: oniloaoj@gmail.com

Received in 22/11/2010

Accepted in 07/02/2011 leishmaniasis (ACL) are single or multiple cutaneous lesions, but there are asymptomatic cases as well ${ }^{1}$.

The laboratory techniques of diagnosis involve methods of detection of the parasite, such as directsearch, isolation in culture, animal inoculation, and histopathology. However, these methods present hurdles related to sensitivity ${ }^{1}$. On the other hand, immunodiagnostic techniques, such as the Montenegro skin test (MST), can increase the speed of the diagnosis, but they are unable to distinguish among active, inactive, or past infection ${ }^{2}$. Historically, a positive MST is an indicator of previous contact with the parasite through natural inoculation. MST is the most widely used complementary test for the presumptive diagnosis of Leishmania infection. Positivity indexes of $84 \%$ and $100 \%$ have been estimated in cutaneous and mucocutaneous forms, respectively. Moreover, MST is negative in cutaneous diffuse form and in immunocompromised patients ${ }^{2}$.

In this context, the use of PCR-based techniques has been shown as a new option of diagnosis, mainly due to their speed and high sensitivity ${ }^{1,3}$. Moreover, these techniques have been developed to amplify mini-exon genes ${ }^{4}$, DNA coding regions for subunits of the ribosomal $\mathrm{RNA}^{5}$, and kinetoplast DNA-kDNA ${ }^{6}$ besides other sequences of nuclear $\mathrm{DNA}^{7}$ in clinical samples for the diagnosis of leishmaniasis. However, a major concern in the development and implementation of PCR for Leishmania diagnosis is the lack of standardization; many reports have been published, but very few studies have compared the different protocols ${ }^{5}$.

One of the main targets of these protocols is the kDNA that contains minicircles, which usually have the size of $1 \mathrm{~kb}$ and occur up to 10,000 copies per parasite ${ }^{8}$. The minicircle $\mathrm{kDNA}$ has a denominated region conserved, with approximately $100-150 \mathrm{bp}$, and a variable one, with approximately $700-1,000 \mathrm{bp}$. Both regions are targets for primers designed to the $\mathrm{PCR}^{8,9}$.

In this work, primers directed to the conserved region - L150/ $\mathrm{L} 152^{9}$ - and to the variable region - 13Y $/ 13 \mathrm{Z}^{8}$ — were used in the PCR. In seminested PCR (snPCR), primers LINR4/LIN17/LIN19 were used to target the variable region, although their alignment was with the conserved region ${ }^{6}$. The positivity of those methods was assessed based on the analysis of the materials obtained from patients suspected for ACL.

For this purpose, DNA was obtained from 39 samples (biopsies and imprints on slides) of patients with suggestive lesions for ACL. 
The patients were from the regions of Southern, Southwestern (SSMG), and Rio Doce Valley (RDV), State of Minas Gerais. Among those patients, 32 ( $82 \%$ ) out of 39 were confirmed positive for ACL by parasitological diagnosis and/or MST. Parasitological diagnosis was done under microscopic analysis of imprints obtained from outer edges of the lesions.

All procedures involving human samples were approved under register number $141 / 2006$ by the Ethics on Human Research Committee from Universidade Federal de Alfenas.

DNA extraction was carried out using proteinase $\mathrm{K}$ digestion of skin biopsies from lesions 9 . In this methodology, DNA extraction from samples was performed with $100 \mu \mathrm{L}$ buffer solution $(10 \mathrm{mmol} / \mathrm{L}$ Tris- $\mathrm{HCl}$ and $1 \mathrm{mmol} / \mathrm{L}$ ethylenediaminetetraacetic acid, $\mathrm{pH} 8.0$ ) and $100 \mu \mathrm{g} / \mathrm{mL}$ proteinase $\mathrm{K}$ (final concentration), incubated at $56^{\circ} \mathrm{C}$ for $3 \mathrm{~h}$, and homogenized from time to time. Digestion was stopped by proteinase K inactivation, by boiling it for $15 \mathrm{~min}$. The samples were centrifuged, and the supernatant was used as the Leishmania template DNA source for the PCR reaction. For slides, the methodology used was extraction based on heating ${ }^{10}$. In this methodology, an area covering two imprints, previously analyzed on microscope, was scraped from each slide with a toothpick, resuspended in $20 \mu \mathrm{L}$ of double-distilled water, and transferred to $0.5 \mathrm{~mL}$ microtubes. The samples were heated at $70^{\circ} \mathrm{C}$ for $10 \mathrm{~min}$ and, then, centrifuged at $12,000 \mathrm{~g}$ for $5 \mathrm{~min}$ at room temperature; after which, the supernatant was used as a DNA template.

DNA obtained from the digestion of biopsies as well as the imprints was submitted to the following three PCR techniques. Amplification was carried out in a Perkin-Elmer GeneAmp PCR System 9,700 thermocycler under different conditions for L150/ $\mathrm{L}_{152^{9}}, 13 \mathrm{Y} / 13 \mathrm{Z}^{8}$, and $\mathrm{snPCR}{ }^{6}$.

For each reaction, a negative control tube containing no template DNA was included. The positive control was also performed consisting of $10 \mathrm{pg}$ of DNA extracted from axenic cultures of Leishmania (Viannia) braziliensis MHOM/BR/1975/M2903 and Leishmania (Leishmania) amazonensis MHOM/BR/1972/M2269. Amplified products were analyzed in a $1.5 \%$ agarose gel, which was stained with ethidium bromide and under $3 \mathrm{~V} / \mathrm{cm}$.

Comparative analysis among the positivity indexes obtained by the three PCR techniques was carried out using the Chi-square test, with the level of significance set at $\mathrm{p}<0.05$. The analysis was carried out using the Epi Info ${ }^{\text {тм }} 6.04 \mathrm{~d}$ (CDC) software?

Results were evidenced by a band of approximately 120, 720, and 670 bp for L150/L152, 13Y/13Z, and snPCR, respectively (Figure 1). The positivity indexes obtained by the three techniques can be seen on Table 1. For ACL suspected cases, a larger percentage of positive results was detected in the L150/L152 PCR (76.9\%) in relation to others assays, although without significant difference $(\mathrm{p}>0.05)$, which was probably due the small number of cases. However, for confirmed cases, in parasitological tests and/or MST, these results were significantly different $(\mathrm{p}<0.05)$.

The performance of L150/L152 in the present work confirmed the results obtained from previous studies ${ }^{9}$. However, it was noted that the snPCR technique has the possibility of detecting and amplifying larger sizes of DNA fragments with similar positivity obtained by L150/L152. Larger DNA targets present lower efficiency of amplification ${ }^{11}$; however, the opposite was observed in the positivity index of snPCR from ACL suspected and confirmed patients.

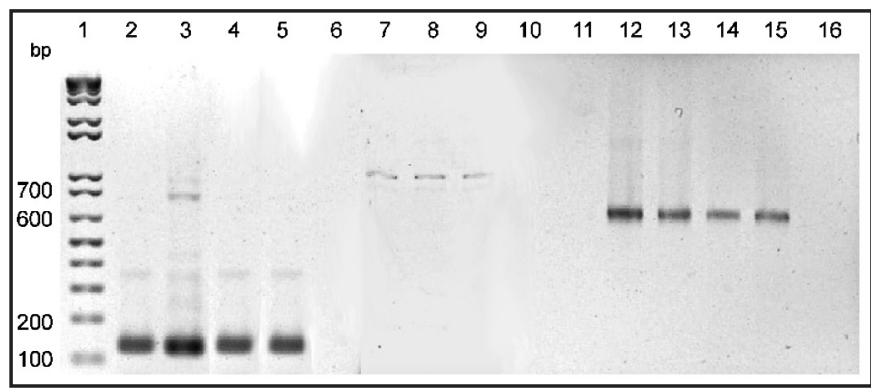

FIGURE 1 - Representative $1.5 \%$ agarose gel showing amplification products of 120 (lanes 2-6, conserved region with L150/L152 primers), approximately 720 (lanes 7-11, variable region with $13 \mathrm{Y} / 13 \mathrm{Z}$ primers), and approximately 670 (lanes $12-16$, variable region with PCRSeminested) bp from kDNA minicircles of Leishmania in promastigote cultures and skin biopsies from american cutaneous leishmaniasis patients.

Lane 1: Molecular size marker of $100 \mathrm{bp}$ ladder; Lanes 2, 7, and 12: DNA from Leishmania (Viannia) braziliensis MHOM/BR/1975/M2903; Lanes 3, 8, and 13: DNA from Leishmania (Leishmania) amazonensis MHOM/BR/1972/M2269; Lane 4-5, 9-10, and 14-15: DNA of skin biopsy samples from ACL patients; Lanes 6, 11, and 16: negative controls.

TABLE 1 - Indices of positivity obtained for the PCR-based techniques applied on biological samples from ACL suspected and confirmed patients.

\begin{tabular}{|c|c|c|c|c|}
\hline \multirow[b]{3}{*}{ PCR technique } & \multicolumn{4}{|c|}{ Positivity index PCR $(\%)^{*}$} \\
\hline & \multicolumn{2}{|c|}{ ACL suspected $(n=39)$} & \multicolumn{2}{|c|}{ PAR and/or MST $+(n=32)$} \\
\hline & $\mathrm{n}$ & $\%$ & $\mathrm{n}$ & $\%$ \\
\hline $13 \mathrm{Y} / 13 \mathrm{Z}$ & 22 & $56.4^{\mathrm{a}}$ & 22 & $68.7^{\mathrm{a}}$ \\
\hline L150/L152 & 30 & $76.9^{a}$ & 30 & $93.7^{b}$ \\
\hline snPCR & 27 & $69.2^{\mathrm{a}}$ & 27 & $84.4^{\mathrm{a}, \mathrm{b}}$ \\
\hline
\end{tabular}

PCR: polymerase chain reaction, snPCR: seminested PCR, ACL: American cutaneous leishmaniasis, PAR: parasitological, MST+: Montenegro skin test, ${ }^{*}$ Chi-square test (significant at $\mathrm{p}<0.05$ ); ${ }^{\mathrm{a}, \mathrm{b}}$ : equal letters mean positivity indexes that are statistically similar.

It was proposed that snPCR test is very sensitive on detection of Leishmania, partly because there can be about 10,000 minicircles per kinetoplast and because its sequences are known for most Leishmania species $^{3}$. Results obtained by Nested PCR using other targets as ITS- 1 showed a lower positivity when compared with snPCR using the $\mathrm{kDNA}^{5}$.

Trypanosoma cruzi DNA was tested by L150/L152, 13Y/13Z, and snPCR to verify possible cross-reaction, but specific fragments were not observed (data not shown). In addition, results of PCR obtained for Leishmania using $13 \mathrm{Y} / 13 \mathrm{Z}$ primers ${ }^{8}$ as well as $\mathrm{snCR}^{3,6}$ did not show cross-reactivity with other trypanosomatids. Cross-reaction and low specificity for $\mathrm{L} 150 / \mathrm{L} 152^{12}$ were observed. Furthermore, to minimize risks of contamination, improvements were done in snPCR in relation to the conventional Nested technique ${ }^{13}$.

Moreover, it was proposed that the control of leishmaniasis in areas of endemicity requires a thorough knowledge of Leishmania ecology and epidemiology and a sensible method for the detection of the parasite, which can be capable of processing a large number of samples synchronously $y^{6}$. In this context, results obtained in three PCR assays show that these techniques can be useful for this purpose. Additionally, these methodologies have been shown capable of detecting kDNA from Leishmania in imprints on slides, where the shortage of material is not a limiting factor ${ }^{10}$.

In conclusion, the preliminary results showed that three PCR assays, mainly L150/L152 and snPCR, can detect Leishmania DNA, including those in biological samples from ACL patients, and 
that they also carry potential application on laboratory diagnosis of leishmaniasis. However, it is important to evaluate a larger amount of samples to verify the trend of L150/L152 and snPCR on producing results with greater positivity and significance, in relation to $13 \mathrm{Y} / 13 \mathrm{Z}$. Other studies are in progress to test the ability of the association of restriction fragment length polymorphism (RFLP) and snPCR on distinction of the different Leishmania species and to identify Leishmania DNA in other populations like dogs with visceral leishmaniasis.

\section{ACKNOWLEDGMENTS}

We thank Mr. Jair Cecílio de Paula for the technical assistance in the Dr. Paulo Araujo Magalhães Leishmaniasis ambulatory.

\section{CONFLICT OF INTEREST}

The authors declare that there is no conflict of interest.

\section{FINANCIAL SUPPORT}

Conselho Nacional de Desenvolvimento Científico e Tecnológico $(\mathrm{CNPq})-19 / 2004-47688$

\section{REFERENCES}

1. Fagundes A, Schubach A, Paula CC, Bogio A, Antonio LF, Schiavoni PB, et al Evaluation of polymerase chain reaction in the routine diagnosis for tegumentary leishmaniasis in a referral centre. Mem Inst Oswaldo Cruz 2010; 105: 109-112.

2. Weigle KA, Labrada LA, Lozano C, Santrich C, Barker DC. PCR-Based diagnosis of acute and chronic cutaneous leishmaniasis caused by Leishmania (Viannia). J Clin Microbiol 2002; 40:601-606

3. Parvizi P, Mauricio I, Aransay AM, Miles MA, Ready PD. First detection of Leishmania major in peridomestic Phlebotomus papatasi from Isfahan province, Iran: comparison of nested PCR of nuclear ITS ribosomal DNA and seminested PCR of minicircle kinetoplast DNA. Acta Tropica 2005; 93:75-83.

4. Paiva BR, Secundino NFC, Nascimento JC, Pimenta PFP, Galati EAB, Andrade Junior HF, et al. Detection and identification of Leishmania species in Field-captured phlebotomine sandflies based on mini-exon gene PCR. Acta Tropica 2006; 99:252-259.

5. Pilatti MM, Ferreira AS, Melo MN, Andrade ASR. Comparison of PCR methods for diagnosis of canine visceral leishmaniasis in conjunctival swab samples. Res Vet Sci 2009; 87:255-257.

6. Aransay AM, Scoulica E, Tselentis Y. Detection and identification of Leishmania DNA in naturally infected sand flies by Seminested PCR on minicircle kinetoplastic DNA. Appl Environ Microbiol 2000; 66:1933-1938.

7. Noyes H, Reyburn H, Bailey JW, Smith D. A nested-PCR-based schizodeme method for identifying Leishmania kinetoplast minicircle classes directly from clinical samples and its application to the study of the epidemiology of Leishmania tropica in Pakistan. J Clin Microbiol 1998; 36:2877-2881.

8. Rodgers MR, Popper SJ, Wirth DF. Amplification of kinetoplast DNA as a too in the detection and diagnosis of Leishmania. Exp Parasitol 1990; 71:267-275.

9. Marques MJ, Volpini AC, Coelho GLLM, Pinto JM, Costa CA, Mayrink W, et al. Comparison of PCR with other laboratorial methods for the diagnosis of American Cutaneous Leishmaniasis. Diagnostic Microbiol Infect Dis 2006; 54:37-43.

10. Volpini AC, Marques MJ, Lopes dos Santos S, Machado-Coelho GL, Mayrink W, Romanha AJ. Leishmania identification by PCR of Giemsa-stained lesion imprint slides stored for up to 36 years. Clin Microbiol Infect Dis 2006; 12:793-821.

11. Cheng S, Fockler C, Barnes WM, Higuchi R. Effective amplification of long targets from cloned inserts and human genomic DNA. Proceed Nat Acad Sci USA 1994; 91: 5695-5699.
12. Rocha LS, Santos CB, Falqueto A, Grimaldi Junior G, Cupolillo E. Molecular biological identification of monoxenous trypanosomatids and Leishmania from antropophilic sand flies (Diptera; Psychodidae) in Southeast Braz Parasitol Res 2010; 107:465-468.

13. Saini R, Santhanam J, Othman NH, Saini D, Tang TH. Single-tube Seminested PCR Assay for detecting Human Papillomavirus in Clinical Samples. Open Microbiol J 2009; 3:106-112. 